\title{
PAPERS
}

\section{Mucosal polyamine metabolism in the columnar lined oesophagus}

\author{
M R Gray, H M Wallace, H Goulding, J Hoffman, W E Kenyon, A N Kingsnorth
}

\begin{abstract}
Mucosal ornithine decarboxylase activity and polyamine content has been proposed as a possible marker for malignant potential in gastrointestinal mucosa. Polyamine content and histological findings were examined in $\mathbf{1 0 7}$ pairs of endoscopic biopsy specimens taken from gastric fundus, fundic and specialised Barrett's oesophagus and Barrett's adenocarcinoma. The content of putrescine (median $\mathrm{nmol} / \mathrm{mg}$ protein, range) the primary product of ornithine decarboxylase showed a progressive increase from gastric fundus $(0.41,0.15-1 \cdot 5)$; fundic (0.45, 0.01-4.08); specialised Barrett's oesophagus $(0.54,0.01-2 \cdot 0)$; dysplastic columnar lined oesophagus $(0 \cdot 56,0 \cdot 31-3 \cdot 1)$ to adenocarcinoma (1.23, 0.29-8.98). Adenocarcinoma putrescine content was significantly greater than gastric fundus $(p<0.018)$ and fundic $(\mathbf{p}<0.03)$. Mucosal spermine, spermidine, and total polyamine values were greater in gastric fundus than fundic, specialised Barrett's oesophagus, and dysplastic columnar lined oesophagus (all $\mathrm{p}<0.001$ ) suggesting failure to further metabolise putrescine to its higher polyamines in the metaplastic epithelium. Although metaplastic columnar lined oesophagus shows significant differences in polyamine metabolic activity from the stomach the important distinction between specialised and dysplastic columnar lined oesophagus cannot be made by measuring the polyamine content. (Gut 1993; 34: 584-587)
\end{abstract}

Department of Surgery, University of Liverpool, Liverpool

M R Gray

A N Kingsnorth

Department of Histopathology, Broadgreen Hospital, Liverpool

H Goulding

J Hoffman

W E Kenyon

Department of Medicine and Therapeutics and Biomedical Sciences, University of Aberdeen, Aberdeen

H M Wallace

Correspondence to:

Mr M R Gray, Marine Villa, Little Lane, Parkgate, Wirral L64 5SD.

Accepted for publication 15 September 1991
Barrett's columnar lined oesophagus (CLO) predisposes to adenocarcinoma of the oesophagus. ${ }^{1}$ Specialised type CLO shows an increased activity in cellular proliferation compared with junctional and fundic types and is recognised as the site of neoplastic change in those patients progressing to adenocarcinoma. ${ }^{23}$ To date histological dysplasia and associated ploidy abnormalities are the only known markers of increased risk of malignancy in CLO. ${ }^{45}$

The polyamines - putrescine, spermidine, and spermine - are intracellular polycations synthesised from ornithine in a rate limiting reaction catalysed by the enzyme ornithine decarboxylase. ${ }^{67}$ Raised values of polyamine synthetic enzyme activity and polyamine content have been suggested as markers of tumour prognosis in breast carcinoma and pre-neoplastic potential in gastrointestinal mucosa ${ }^{8-10}$ Inhibition of poly- amine biosynthesis reduces the tumour yield in animal models of carcinogenesis. ${ }^{11}$

In Barrett's oesophagus ornithine decarboxylase activity is increased in some cases of dysplasia. $^{12}$ In one patient dysplasia was accompanied by a rise in ornithine decarboxylase activity suggesting that ornithine decarboxylase activity and polyamine biosynthesis may have potential as a non-histological marker of dysplasia in CLO ${ }^{13} \mathrm{~A}$ previous report has failed to show a direct relation between polyamine content in CLO and concurrent ornithine decarboxylase activity, possibly reflecting the labile nature of ornithine decarboxylase. ${ }^{14}$ Polyamines have a longer half life than the ornithine decarboxylase enzyme activity and are less labile. Polyamines can be assayed, after perchloric acid extraction, by high pressure liquid chromatography in a semi-automatic way. For this reason a pilot study was done to assess the possibility of using mucosal polyamine estimations as a nonhistological marker of dysplasia in Barrett's oesophagus.

\section{Patients and methods}

One hundred and seven pairs of endoscopic biopsy specimens were taken from the upper Barrett's oesophagus ( $1 \mathrm{~cm}$ below the squamocolumnar junction); lower Barrett's oesophagus ( $4 \mathrm{~cm}$ below the squamocolumnar junction), and gastric fundus from 40 patients with simple metaplastic CLO and eight patients with malignant change in CLO. The biopsy specimens were placed immediately in pre-labelled cryotubes and immersed in liquid nitrogen. They were stored at $-70^{\circ} \mathrm{C}$ until perchloric acid extraction. After extraction biopsy protein content was assayed by the Coomassie blue technique and polyamine content was measured by high pressure liquid chromatolography. Adjacent biopsy specimens were processed routinely for histological examination.

PERCHLORIC ACID EXTRACTION OF POLYAMINES Polyamines are acid soluble whereas protein is acid insoluble, hence extraction in perchloric acid allows separation of the two. Biopsy specimens were taken from the liquid nitrogen and placed in $1 \mathrm{ml}$ of ice cold perchloric acid $(0.2 \mathrm{M})$ in a Jencons hand homogeniser. After homogenisation the suspension was transferred to a glass bijou and sonicated for 30 seconds on ice using a 


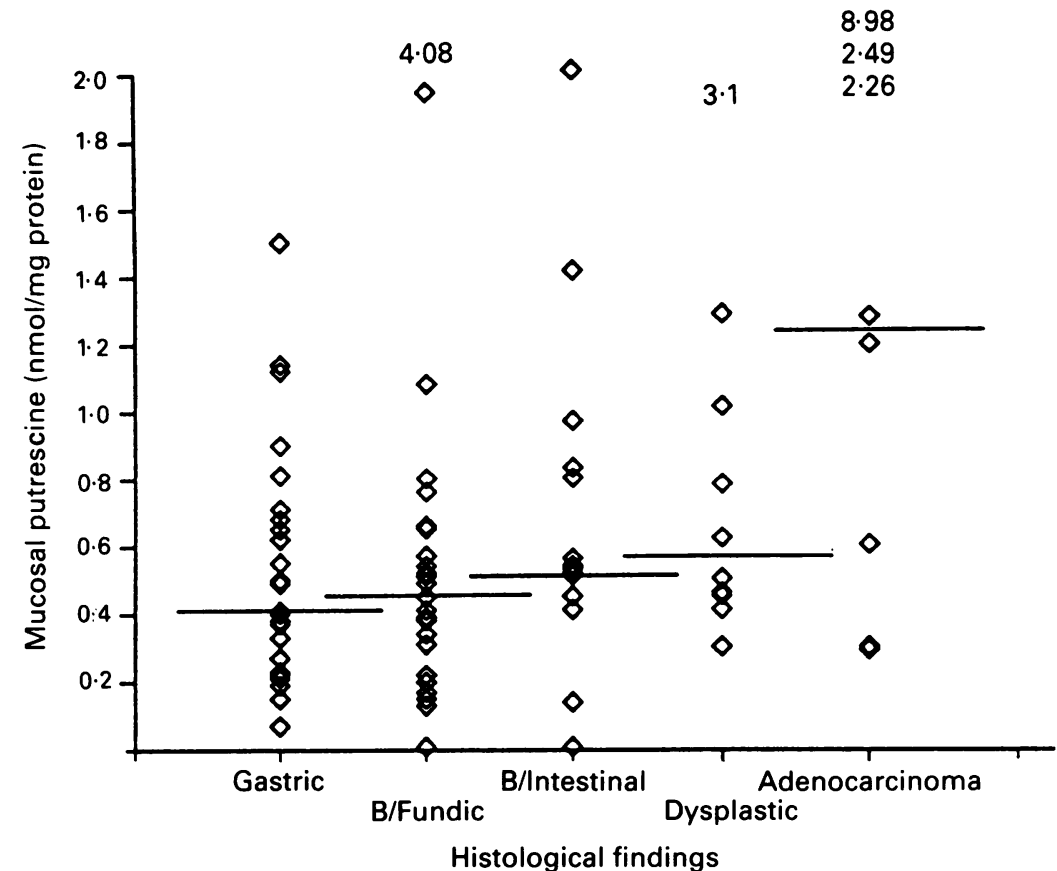

Figure 1: Mucosal putrescine.

Rapidis 150 ultrasonicator (Ultrasonics Ltd, Simpley, Yorkshire). Cell disruption was checked by microscopy. The suspension was then allowed to stand on ice for 15 minutes. Samples were then centrifuged at $13000 \mathrm{rpm}$ at $4^{\circ} \mathrm{C}$ in an Eppendorf microcentrifuge. The supernatant and the protein pellets were transferred to a cryotube and frozen at $-20^{\circ} \mathrm{C}$. Protein and polyamines were assayed separately in batches.

\section{PROTEIN ASSAY}

Pellets were suspended again in $1 \mathrm{ml} 0.3 \mathrm{M}$ sodium hydroxide that required incubation in a $40^{\circ} \mathrm{C}$ water bath overnight. Protein was assayed by the Coomassie blue technique. ${ }^{15}$ Triple serial dilutions of protein were prepared. $0 \cdot 1 \mathrm{ml}$ of

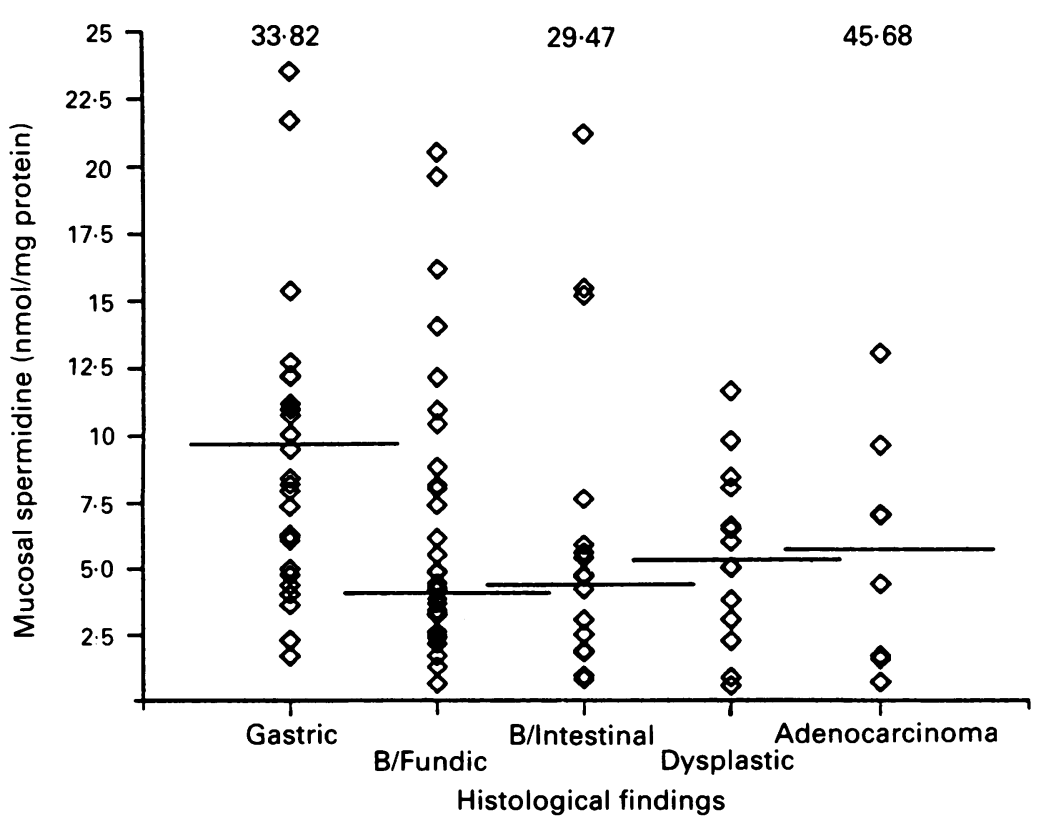

Figure 2: Mucosal spermidine. protein suspension was used and a standard curve was constructed for each assay performed using a bovine serum albumin standard (Sigma Diagnostics) suspended in $0.3 \mathrm{M}$ sodium hydroxide between 0 and $1400 \mathrm{mg}$ protein $/ \mathrm{ml}$.

\section{HIGH PRESSURE LIQUID CHROMATOGRAPHY FOR} POLYAMINES

Polyamines were quantified by high pressure liquid chromatography after the method of Wallace et al. ${ }^{16}$ Briefly, individual polyamines were separated using reverse phase high pressure liquid chromatography with the ion pair reagent, octane sulphonic acid, used to aid separation. The column effluent was mixed 1:1 with o-phthaldealdehyde reagents to produce derivatives which were quantified by fluorescence spectrometry.

\section{Results}

The results of the mucosal polyamines are expressed in $\mathrm{nmol} / \mathrm{mg}$ protein. The results are grouped by histological type into gastric fundus $(n=32)$, fundic type CLO $(n=34)$, specialised type CLO $(n=19)$, dysplastic CLO taken from patients with adenocarcinoma $(n=11)$ and Barrett's adenocarcinoma $(n=10)$.

The mucosal putrescine content showed a progressive increase from gastric fundus (median $0.41 \mathrm{nmol} / \mathrm{mg}$ protein; range $0.15-1.5 \mathrm{nmol} / \mathrm{mg}$ ) to fundic type CLO (median $0.45 \mathrm{nmol} / \mathrm{mg}$; range $0.01-4.08 \mathrm{nmol} / \mathrm{mg}$ ) to specialised CLO (median $0.54 \mathrm{nmol} / \mathrm{mg}$; range $0.01-2.0 \mathrm{nmol} /$ $\mathrm{mg}$ ), dysplastic CLO (median $0.56 \mathrm{nmol} / \mathrm{mg}$ range $0 \cdot 3-3 \cdot 1 \mathrm{nmol} / \mathrm{mg}$ ), and adenocarcinoma (median $1.23 \mathrm{nmol} / \mathrm{mg}$; range $0.29-8.98 \mathrm{nmol} /$ $\mathrm{mg}$ ). Only adenocarcinoma, however, showed a significant difference from gastric fundus $(p<0.018)$ or fundic type CLO $(p<0.03)$. No significant difference was seen between dysplastic and non-dysplastic CLO. (Fig 1).

Spermidine values in gastric fundus (median $9.77 \mathrm{nmol} / \mathrm{mg}$; range $1.69-33.82 \mathrm{nmol} / \mathrm{mg}$ ) were significantly higher than in fundic type CLO (median 4.38; range $0.64-20.45 \mathrm{nmol} / \mathrm{mg}$ ) $(\mathrm{p}<0.005$ ), specialised type CLO (median 4.89 ; range $0.94-29.47 \mathrm{nmol} / \mathrm{mg})(\mathrm{p}<0.002)$, and dysplastic CLO (median 5.98; range 0.62-8.05 $\mathrm{nmol} / \mathrm{mg})(\mathrm{p}<0.03)$. Adenocarcinoma (median 6.97; range $0.7-45.68 \mathrm{nmol} / \mathrm{mg}$ ) showed no significant difference. (Fig 2).

Spermine values in gastric fundus (median $17.57 \mathrm{nmol} / \mathrm{mg}$; range $0.73-54.31 \mathrm{nmol} / \mathrm{mg}$ ) exceeded those of fundic CLO (median 8.93; range $1.39-33.95 \mathrm{nmol} / \mathrm{mg})(\mathrm{p}<0.005)$, specialised CLO (median $5 \cdot 11$, range $0.94-34 \cdot 44 \mathrm{nmol} /$ $\mathrm{mg}$ ), and dysplastic CLO (median $7 \cdot 75$; range $2 \cdot 48-11.36 \mathrm{nmol} / \mathrm{mg})(\mathrm{p}<0 \cdot 006)$. Adenocarcinoma (median $8 \cdot 89$; range $3 \cdot 20-94.02 \mathrm{nmol} /$ $\mathrm{mg}$ ) was not significantly different as a group. No difference was seen between intestinal and dysplastic CLO. (Fig 3).

Total polyamines in gastric fundus (median $29.04 \mathrm{nmol} / \mathrm{mg}$; range $3.08-98.63 \mathrm{nmol} / \mathrm{mg}$ ) exceeded those in fundic CLO (median 14.09 $\mathrm{nmol} / \mathrm{mg}$; range $0 \cdot 73-55.44 \mathrm{nmol} / \mathrm{mg}$ ), specialised CLO (median 10.63; range 0.34-51.08 $\mathrm{nmol} / \mathrm{mg}) \quad(\mathrm{p}<0 \cdot 006)$, and dysplastic CLO 


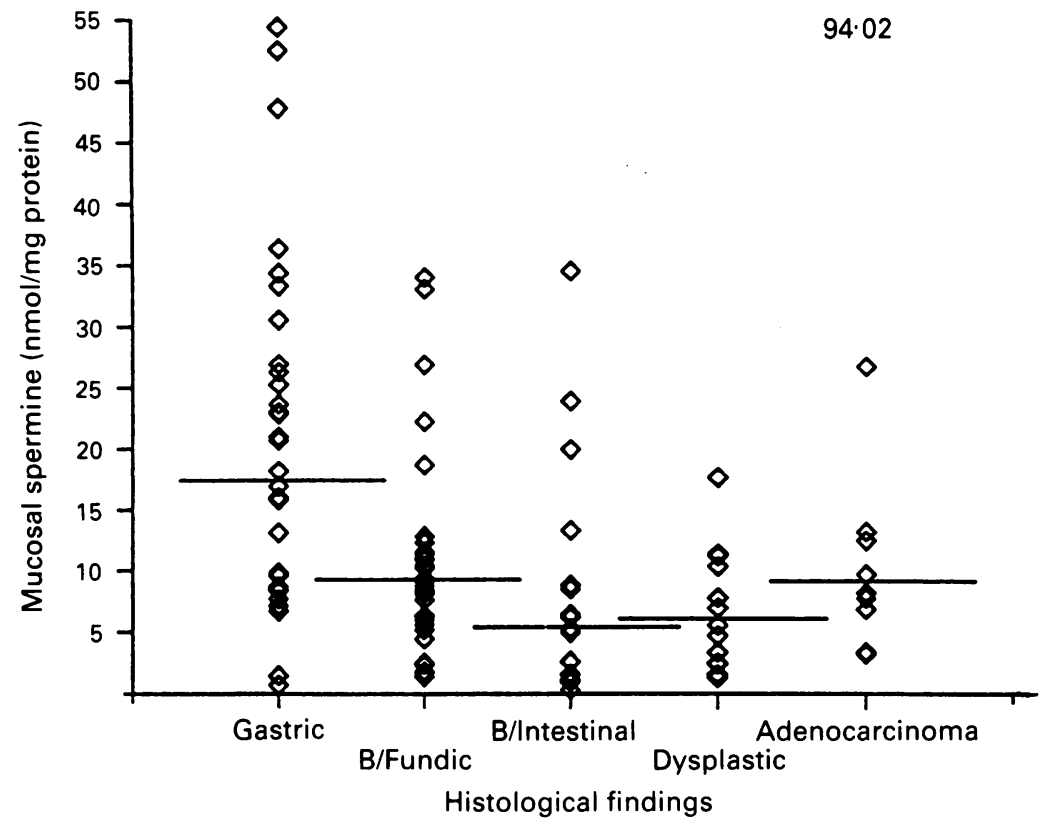

Figure 3: Mucosal spermine.

(median $14.49 \mathrm{nmol} / \mathrm{mg}$; range $2 \cdot 48-30.54 \mathrm{nmol} /$ $\mathrm{mg})(\mathrm{p}<0.003)$. Again adenocarcinoma as a group were similar to gastric fundus (median $18.7 \mathrm{nmol} / \mathrm{mg}$; range $5.07-148.68 \mathrm{nmol} / \mathrm{mg}$ ) and no difference could be detected between specialised and dysplastic CLO. (Fig 4.)

The spermine to spermidine ratio in gastric fundus (median 2.065; range 0.88-3.62) was similar to fundic CLO (1.85; range $0 \cdot 32-3 \cdot 74)$. Gastric fundus ratio exceeded both specialised CLO (median $1 \cdot 16$; range $0 \cdot 18-2 \cdot 80$ ) $(\mathrm{p}<0.002)$ and dysplastic CLO (median 1.34; range $0.65-3.65)(\mathrm{p}<0.036)$ but not adenocarcinoma (median 1.43; range $0 \cdot 73-37 \cdot 9$ ). Again there was no difference between specialised and dysplastic CLO. (Fig 5.)

\section{Discussion}

The finding that total mucosal polyamine and

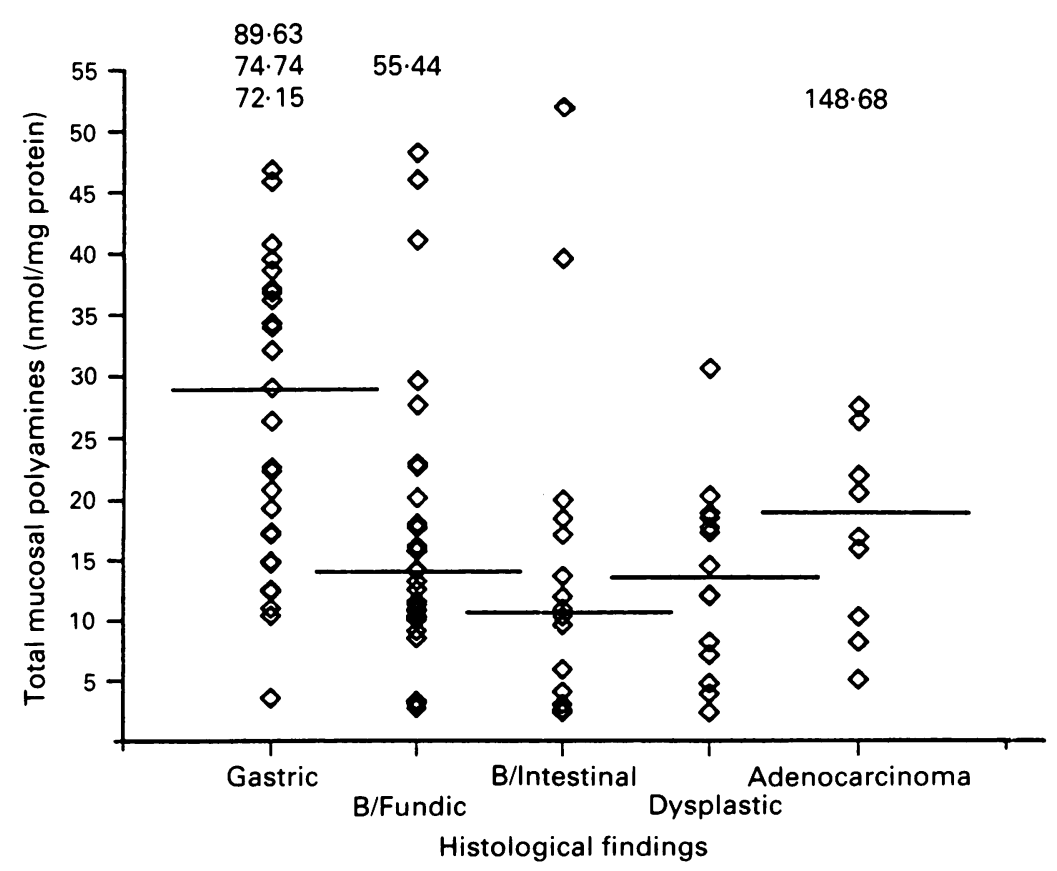

Figure 4: Total mucosal polyamines. individual higher polyamine (spermidine and spermine) content in the gastric fundus exceeded that of the Barrett's mucosa was unexpected. The implication of this finding is that mucosal polyamines are not useful as markers of dysplasia in CLO because biopsy specimens taken from normal fundus have a higher polyamine content than metaplastic or dysplastic CLO. Further, although CLO showed significantly lower values than gastric fundus, polyamine content did not differ significantly between dysplastic and specialised CLO.

An important feature of the polyamines is their ionic interactions with the DNA double helix where they play a part in helping DNA replication and RNA transcription. ${ }^{17}{ }^{18}$ Polyamines are absolute requirements for progression through the cell cycle and depletion can lead to failure of recruitment of cells into $G_{1}$ from $G_{0}$, lack of progression through the $S$ phase, and interference with mitosis causing the formation of binucleate cells. ${ }^{19}$ Ornithine decarboxylase is rapidly inducible and has a short half life (10-15 minutes). A rise in ornithine decarboxylase activity and a consequent increase in the polyamine content to tissues is characteristic of gastrointestinal proliferation seen in response to weaning, mucosal injury, or resection. ${ }^{19-24} \mathrm{An}$ increase in the spermine to spermidine ratio is seen in proliferating cells in culture. ${ }^{24} \mathrm{~A}$ ratio of $1 \cdot 5-2.0$ is indicative of rapid proliferation and a fall in the ratio is seen inconfluent cell culture. ${ }^{25}$ Thus there is an established link between polyamine content and physiological gastrointestinal epithelial proliferation.

Tissue putrescine values are related most closely to ornithine decarboxylase activity and in this study of patients with columnar lined oesophagus mucosal putrescine content increased in a graded fashion from gastric fundus to adenocarcinoma. These small increments did not reach statistical significance other than to distinguish gastric fundus from adenocarcinoma; this is not the clinical problem faced. Distinction between specialised and dysplastic CLO cannot be made on this basis.

Our findings agree with a small study on ornithine decarboxylase activity and polyamine values in CLO in which mucosal polyamine content was unrelated to ornithine decarboxylase activity and higher values of total polyamines were found in the gastric and small intestinal mucosa compared with the metaplastic columnar mucosa. ${ }^{14}$ Possible explanations for the lack of correlation between polyamine content and ornithine decarboxylase activity include the known fluctuations of ornithine decarboxylase activity in response to a large number of influences including diurnal rhythm and feeding, whereas polyamine content fluctuates less rapidly. ${ }^{19-24}$ In addition proliferating gastrointestinal epithelium can take up polyamines derived from the circulation and also by the transportation of polyamines from the intestinal lumen; polyamines may be ingested in food or taken from bacteria. Animal models of proliferation associated polyamine metabolism in gastrointestinal mucosa using germ free animals and diflouromethyl-ornithine inhibition of ornithine decarboxylase activity, suggest that uptake of circulating polyamines 


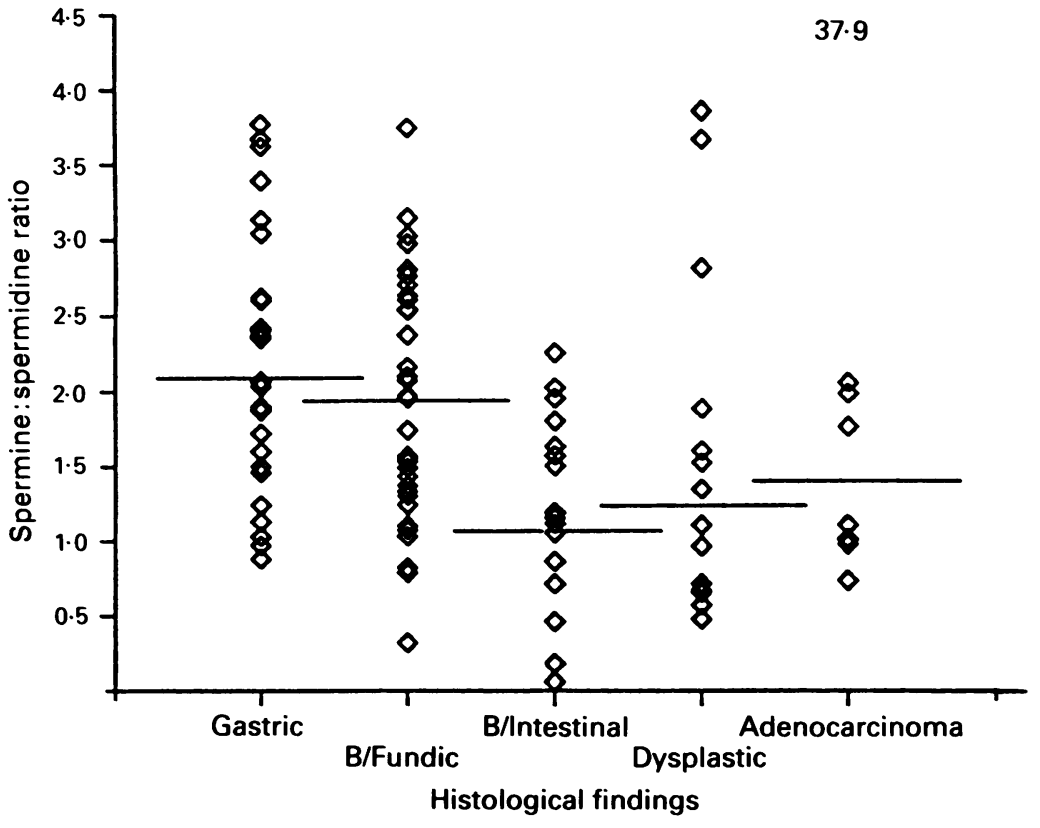

Figure 5: Mucosal spermine/spermidine ratio. across the basolateral membrane is the dominant extramucosal source of higher polyamines. ${ }^{26}$

Another possible reason for the unexpected finding of a lower polyamine content in CLO compared with gastric fundic mucosa might be related to the gastrointestinal hormone state of these patients. All the patients studied took either $\mathrm{H}_{2}$ antagonists or omeprazole as part of their treatment for anti-reflux. A sustained rise in serum gastrin is seen in patients taking omeprazole and post-prandial gastrin is increased in patients taking $\mathrm{H}_{2}$ antagonists. ${ }^{27}$ Gastric fundic mucosal polyamine synthesis may be stimulated by increased gastrin release as a result of therapeutic acid suppression. ${ }^{29}$ Alternatively, gastrin might act by promoting further metabolism of putrescine to the higher derivates.

A trial of short term low dose diflouromethylornithine (specific ODC inhibitor) has shown decreased mucosal polyamine values in metaplastic CLO as well as in all other upper gastrointestinal mucosae. ${ }^{30}$ This suggests that polyamine biosynthesis can be manipulated in CLO with possible treatment implications for patients with dysplastic CLO; although the suppression of gastric adenocarcinoma cell growth in vitro has not found a useful clinical role in vivo. ${ }^{31}{ }^{32}$ Depression of mucosal polyamine content was not specific to the metaplastic mucosa in the CLO patients but dysplastic mucosa may be more vulnerable to ornithine decarboxylase inhibition because of the higher rate of cell turnover and more reliant on ornithine decarboxylase for the production of the higher polyamines. This hypothesis remains to be tested.

1 Gray MR, Donnelly RJ, Kingsnorth AN. Role of salivary epidermal growth factor in the pathogenesis of Barrett's columnar lined oesophagus. Br $\mathcal{F}$ Surg 1991; 78: 1461-6.

2 Gray MR. Barrett's oesophagus and ulcerative complication of reflux oesophagitis. Gullet 1993; 3 (Suppl): 42-52.

3 Gray MR, Hall PA, Nash J, Ansari B, Lane DP, Kingsnorth
AN. Epithelial proliferation in Barrett's oesophagus - by PCNA immunolocalisation. Gastroenterology 1992; 103: 1769-76.

4 Dent J, Bremner CG, Collen RC, Haggitt, Spechler SJ. Working party report to the world congress of gastroenterology, Sydney 1990. Barrett's oesophagus. $\mathcal{J}$ Gastroentero Hepatol 1991; 6: 1-2

5 Rabinovitch PS, Reid BJ, Haggit RC, Norwood TH, Rubin CE. Progression to cancer in Barrett's esophagus is associated with genomic instability. Lab Invest 1988; 60: 65-71.

6 Chayen R. Clinical chemistry of polyamines. Cell Biochem Funct 1984; 2: 15-20.

7 Pegg AE. Polyamine metabolism and its importance in neoplastic growth and as a target for chemotherapy. Cancer $R e s$ plastic growth and

8 Kingsnorth AN, Wallace HM, Bundred NJ, Dixon JMJ. Polyamines in breast cancer. Br $\mathcal{Y}$ Surg 1984; 71: 352-6.

9 Luk GD, Baylin SB. Ornithine decarboxylase as a biological marker in familial colonic polyposis. $N$ Engl f Med 1984 311: 80-3.

10 Saydjari R, Townsend CM, Barranco SC, Thompson JC Polyamine in gastrointestinal cancer. Dig Dis Sci 1989; 34: $1629-36$.

11 Kingsnorth AN, King WWK, Diekema KA, McCann PP, Ross JS, Malt RA. Inhibition of ornithine decarboxylase with 2-difluoromethylornithine: reduced incidence of dimethylhydrazine-induced colon tumours in mice. Cancer Res 1983; 43: 2545-9.

12 Garewal HS, Sampliner R, Gerner EW, Steinbronn K, Alberts DS, Kendall DS. Ornithine decarboxylase activity in Barrett's esophagus: a potential marker for dysplasia. Barrett's esophagus: a potential

13 Garewal HA, Sampliner R, Alberts D, Steinbronn K. Increase in ornithine decarboxylase activity associated with development of dysplasia in Barrett's esophagus. Dig Dis Sci 1989 34: $312-4$.

14 Garewal HS, Gerner EW, Sampliner RE, Roe D. Ornithine decarboxylase and polyamine levels in columnar upper gastrointestinal mucosa in patients with Barrett's esophagus. Cancer Res 1988; 48: 3288-91.

15 Bradford MM. A rapid and sensitive method for the quantitation of microgram quantities of protein using the principle of protein-dye binding. Anal Biochem 1976; 72: 248-54.

16 Wallace HM, Nuttall ME, Robinson F. Acetylation of spermidine and methylglyoxal-bis (guanylhydrazine) in baby mamster kidney cells (BKH-21/C13). Biochem $\mathcal{f}$ 1988; 253: hamster

17 Damani A, Liquori AM, Puliti R, Ripamonti A. X ray study of spermidine tetrahydrochloride. I Mol Biol 1965; 11 438-40.

18 Marton LJ, Feuerstein BG. Polyamine-DNA interactions: possible site of new cancer chemotherapeutic intervention. Pharm Res 1986; 3: 311-7.

19 Heby O. Role of polyamines in the control of cell proliferation and differentiation. Differentiation 1981; 19: 1-20.

20 Thirumalai CHR, Tseng C-C, Tabata $K$, Fitzpatrick LR Johnson LR. Relationship between ornithine decarboxylase activity and gastric damage. Am J Physiol 1987; 253: Gl-6.

21 Tabata K, Johnson $L$. Ornithine decarboxylase and mucosal growth in response to feeding. Am $\mathcal{f}$ Physiol 1986; 251: G270-4.

22 Luk GD, Marton LJ, Baylin SB. Ornithine decarboxylase is important in intestinal mucosal maturation and recovery from injury in rats. Science 1980; 58: 851-5.

23 Hosomi M, Stace NH, Lirussi F, Smith SM, Murphy GM Dowling RH. Role of polyamines in intestinal adaptation in the rat. Eur f Clin Inoest 1987; 17: 375-85.

24 McNeil NO, Eikenburg BE, Johnson LR. Role of ornithine decarboxylase in functional development of rat gastric mucosa. Am f Physiol 1987; 252: G466-71.

25 Wallace HM. Changes in polyamine content in primary cultures of adult rat hepatocytes. Biochem Pharmacol 1989; 38: 379-83.

26 Bardocz $S$. The role of basolateral polyamine uptake in intestinal adaptation. In: Dowling RH, Folsch UR, Loser C eds. Polyamines in the gastrointestinal tract. Falk symposium 62. Dordrecht: Kluwer Academic, 1991.

27 Jansen JBM, Klinkenberg-Kohl EC, Meuwissen SGM, D Bruijne JW. Effect of long term treatment with omeprazole on serum gastrin and serum group $A$ and $C$ pepsinogens in patients with reflux oesophagitis. Gastroenterology 1990; 99: 621-8.

28 Karnes RJ, Berlin RG, Maxwell V, Sytnik B, Root JK, Walsk JH. Prolonged inhibition of acid secretion causes hypergastrinaemia without altering $\mathrm{pH}$ inhibition of gastrin
release in humans. Aliment Pharmacol Ther 1990; 4: 443-56.

29 Johnson LR, Tseng C-C, Tipnis UR, Haddox MK. Gastric mucosal ornithine decarboxylase: localization and stimulamucosal ornithine decarboxylase: localization and

30 Garewal HS, Sampliner RE, Fennerty MB, Gerner E. Low dose difluoromethylornithine (DFMO) produces significant changes in polyamine content of upper $\mathrm{GI}$ mucosa in patients with Barrett's esophagus. Gastroenterology 1991; 100: A364

31 Kingsnorth AN. The chemotherapeutic potential of polyamine antimetabolites. Ann R Coll Surg Engl 1986; 68: 76-81.

32 Barranco SC, Ford PJ, Townsend CM. Cell cycle kinetics responses of human stomach cancer cells to reduction in polyamine levels by treatment with a-difluoromethylornithine in vitro. Invest New Drugs 1986; 4: 347-57. 